\title{
Review
}

【特集：日本小坚循環器学会第 14 回教育セミナー】

\section{ここまで知っておきたい心筋症： 解剖から分子医学まで}

\author{
廣野 恵一 \\ 富山大学医学部小児科
}

\section{Cardiomyopathies: From Anatomy to Molecular Medicine}

\author{
Keiichi Hirono \\ Department of Pediatrics, Toyama University Hospital, Toyama, Japan
}

\begin{abstract}
Cardiomyopathies are defined as abnormalities of the ventricular myocardium. Pediatric cardiomyopathies are rare diseases. Increasingly, the importance of genetic mutations in the pathogenesis of isolated or syndromic pediatric cardiomyopathies is becoming apparent. Pediatric cardiomyopathies are genetically heterogeneous with many different causative genes and multiple mutations in each gene. Variants in the same gene can cause different phenotypes, and variants in different genes can cause the same cardiomyopathy phenotype. There are multiple modes of inheritance for cardiomyopathies, including autosomal dominant, autosomal recessive, $\mathrm{X}$-linked, and mitochondrial. Published guidelines have recommended approaches for genetic testing and family screening in patients with isolated, autosomal-dominant cardiomyopathy. The increasing application of genomic analysis to the pediatric cardiomyopathy population is creating a wealth of information that requires expanded registry participation to further understanding of the pathogenic mechanisms underlying pediatric cardiomyopathies and the genetic, environmental, and other, as of yet undiscovered, modifying factors that impact the severity of disease. This compendium summarizes current knowledge of the genetic and molecular origins of the most common phenotypic presentations of pediatric cardiomyopathies and highlights key areas where additional research is required.
\end{abstract}

Keywords: cardiomyopathy, gene, variant

心筋症とは, 心筋の器質的あるいは電気的異常を有する多様な疾患群と定義され, 原因はしばしば遺 伝性である. 主な病変が心臓にあるものを一次性心筋症, 全身疾患の心筋病変を二次性心筋症と大別 される. 小児の心筋症では様々な遺伝子に様々な変異があり, 遺伝的多様性が特徵である. 遺伝形式 も常染色体顕性, 常染色体潜性, X 連鎖性, ミトコンドリア性と様々である. 遺伝性心筋症の特徵と して, 同一遺伝子内の異なる変異は異なる病型を示すこと, 遺伝子変異の多くが稀で同一のホットス ポットや変異を有することは稀であること, 同一の家族内でも様々な浸透率を示すことが挙げられる. また，同一の遺伝子変異を有していたとしても，臨床経過，転帰は同一家族内でも様々である. 家族 を含めた遺伝学的検査を行うことが重要であり, 今後のさらなる心筋症の病態解明が不可欠である.

はじめに

心筋症とは, 2006 年の米国心臓協会 (AHA) では 「通常不適切な心室の肥大や拡大を呈するような心筋 の器質的あるいは電気的異常を有する多様な疾患群」 と定義され，「その原因は多岐にわたるがしばしば遺
伝性」である。そして主な病変が心蔵にあるものを一 次性心筋症, 全身疾患の心筋病変を二次性心筋症と大 別している (Fig. 1, Table 1). 一次性心筋症は遺伝性, 混合型 (遺伝と後天性), 後天性の 3 つに分類される. 本稿では, 心筋の微細構造について概説し, 一次性 心筋症として, 肥大型拡張症, 拡張型心筋症, 心筋緻

著者連絡先：干930-0194 富山県富山市杉谷 2630 富山大学医学部小児科 廣野恵一

doi: $10.9794 /$ jspccs.34.111

(C) 2018 Japanese Society of Pediatric Cardiology and Cardiac Surgery 


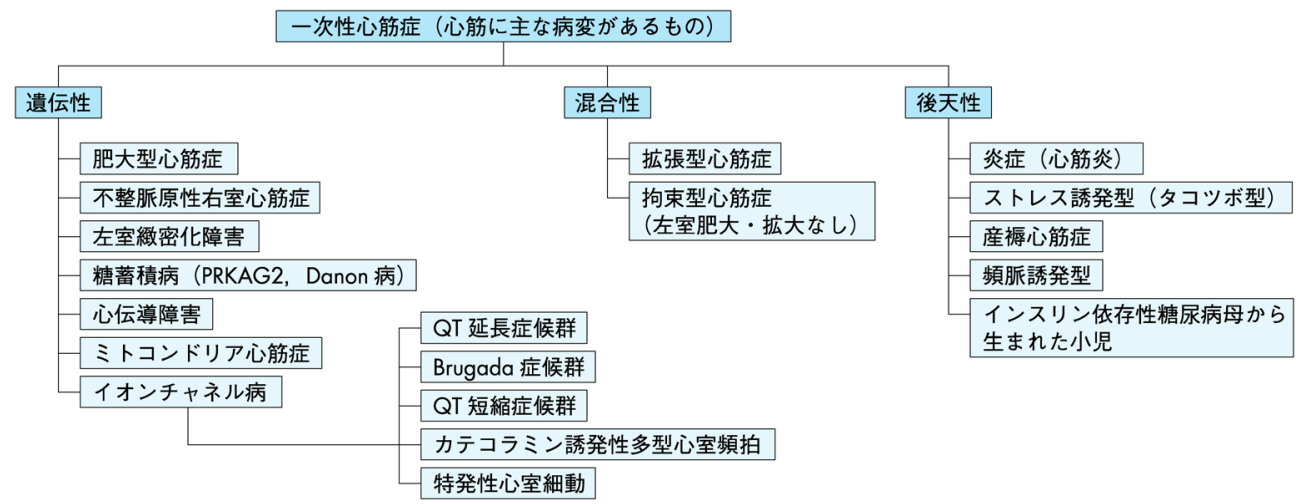

Fig. 1 Current classifications of Cardiomyopathies

The 2006 American Heart Association classification proposes genetics-based classification; primary cardiomyopathies. Modified from Maron BJ, et al. Circulation 2006; 113: 1807-1816

Table 1 Current classifications of Cardiomyopathies

\begin{tabular}{|c|c|}
\hline 浸潤性 & $\begin{array}{l}\text { アミイドーシス，Gaucher 病，Hurler 病， } \\
\text { Hunter 病 }\end{array}$ \\
\hline 蓄積性 & $\begin{array}{l}\text { ヘモクロマトーシス，Fabry 病，糖原病 } \\
\text { (Pompe 病)，Niemann-Pick 病 }\end{array}$ \\
\hline 毒物性 & 薬剤，重金属，化学物質 \\
\hline 心内膜心筋症 & $\begin{array}{l}\text { 心内膜線維症， } \\
\text { 特発性好酸球増多症（Löeffler 症候群） }\end{array}$ \\
\hline 炎症性（肉芽腫） & サルコイドーシス \\
\hline 内分泌性 & $\begin{array}{l}\text { 糖尿病，甲状腺機能六進症， } \\
\text { 甲状腺機能低下症，副甲状腺機能六進症， } \\
\text { 褐色細胞腫，末端肥大症 }\end{array}$ \\
\hline 頭蓋顔面 & Noonan 症候群，多発性黒子症候群 \\
\hline 神経・筋疾患 & $\begin{array}{l}\text { Friedreich 失調症， Duchenne-Becker 筋ジ } \\
\text { ストロフィー，Emery-Dreifuss 筋ジストロ } \\
\text { フィー，筋強直性ジストロフィー，神経線維 } \\
\text { 腫症，結節性硬化症 }\end{array}$ \\
\hline 栄養障害 & $\begin{array}{l}\text { 脚気衝心，ペラグラ，壞血病，セレン， } \\
\text { カルニチン，Kwashiorkor }\end{array}$ \\
\hline 自己免疫・膠原病 & $\begin{array}{l}\text { 全身エリテマトーデス，皮膚筋炎， } \\
\text { 関節リウマチ，強皮症，結節性多発動脈炎 }\end{array}$ \\
\hline \multicolumn{2}{|l|}{ 電解質異常 } \\
\hline 癌治療後 & $\begin{array}{l}\text { アントラサイクリン系，シクロフォスファミド， } \\
\text { 放射線 }\end{array}$ \\
\hline
\end{tabular}

The 2006 American Heart Association classification proposes genetics-based classification; secondary cardiomyopathies. Modified from Maron BJ, et al. Circulation 2006; 113: 1807-1816

密化障害，ミトコンドリア心筋症と二次性心筋症の遺 伝学的要因について概説する.

\section{I. 心筋細胞の微細構造}

心臟には主に心筋細胞，線維芽細胞，血管内皮細胞 の 3 種類の細胞が存在する。心筋細胞が心臟体積のほ ぼ $90 \%$ 占めるが, 細胞数ではこれらの3 種はほぼ 同等とも考えられている，心筋細胞の周りには線維芽
細胞が産生したコラーゲンやラミニンなどの結合組織 が豊富に存在し，さらに毛細血管が心筋細胞に酸素や 栄養素を供給している.

\section{II. 心筋細胞}

心筋細胞は細胞質に豊富な筋原線維 (myofibril) を もち，休むことなく収縮一弛緩を繰り返すことに分化 した細胞である，心筋細胞には基本的な収縮ユニット である筋原線維と, 興奮収縮連関に重要なカルシウム イオンの貯蔵庫である筋小胞体 (sarcoplasmic reticulum)，心筋収縮に必要な ATP の供給源であるミトコ ンドリア，核 (多核) が存在する（Fig. 2).

\section{1．収縮蛋白}

心筋細胞は，ミオシンを主成分とする thick filament とアクチンを主成分とする thin filament，が高 度に組織化された筋原線維により満たされている。ア クチン線維が付着する 2 本の Z 帯に挟まれた $2.2 \mu \mathrm{m}$ （静止時）の収縮単位は，サルコメア（sarcomere）と 呼ばれる.

(1) thick filament : ミオシン重鎖 (myosin heavy chain: MHC）は，分子量 $520 \mathrm{kDa}$ (キロダルトン）の 6 量体蛋白で, 2 個の重鎖 $(220 \mathrm{kDa})$ と 4 個の軽鎖 (20 kDa) より構成される. head, neck, tail の 3 ド メインに分けられる，心筋細胞には， $\alpha$-MHC と $\beta$-MHCの 2 種類のアイソフォームが発現する. ヒ トでは心房筋に $\alpha-\mathrm{MHC}$ が，心室筋に $\beta-\mathrm{MHC}$ が発 現する（マウスやラットの心室筋では，生後収縮能 の早い $\alpha$-MHC が発現する).

・ head domain：アクチンおよび ATP が結合し, 収 縮力を発生する部分. 


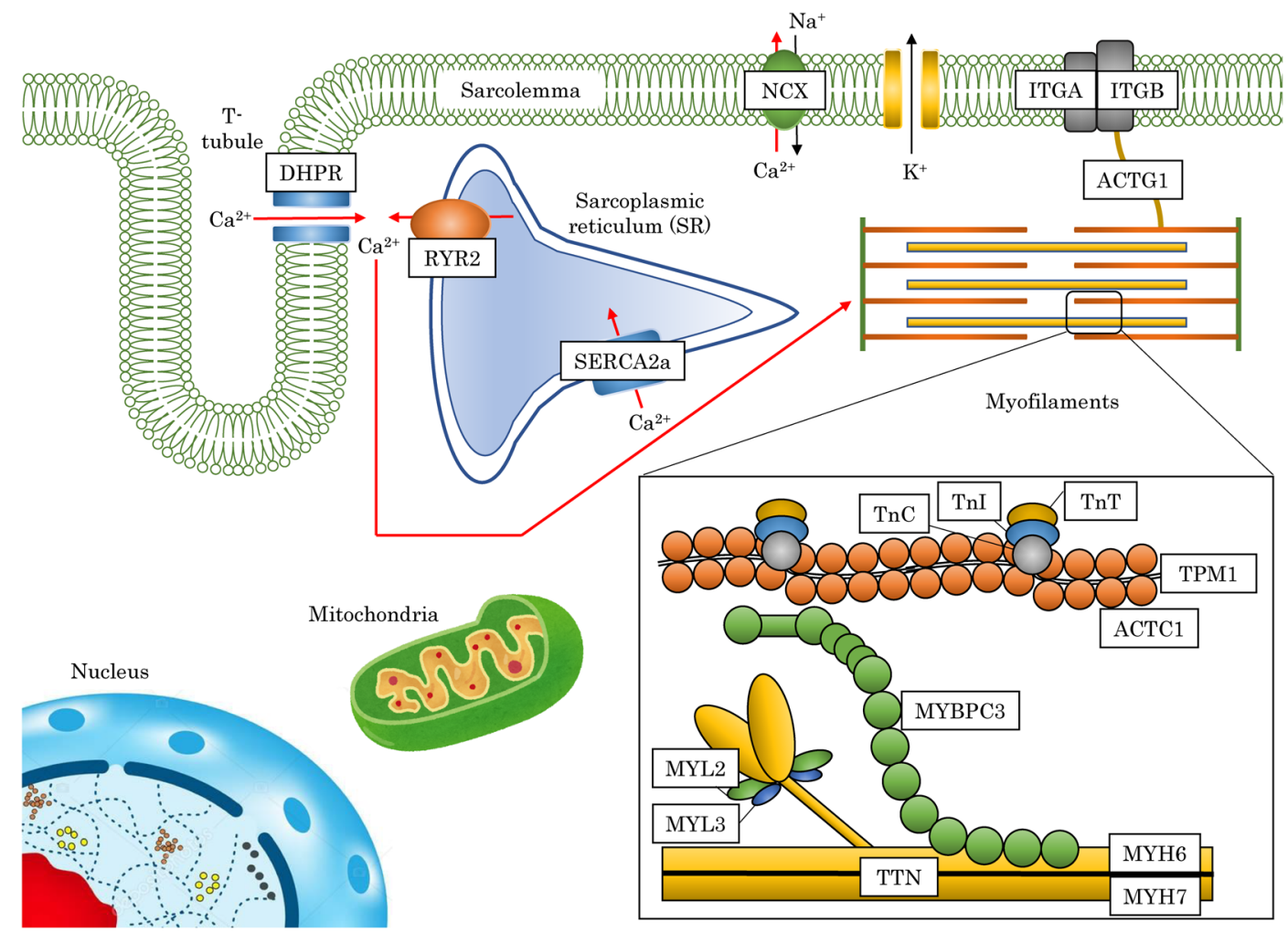

Fig. 2 Locations of genes known to cause cardiomyopathies

・neck domain：ミオシン軽鎖が結合する部分.

・ tail domain： $\alpha$ ヘリックス構造をなす棒状の部分で thick filament $の$ 主要構成成分.

(2) thin filament : アクチン (actin) は球状の $44 \mathrm{kDa}$ 蛋白質で, 2 本鎖がヘリックス構造をなし, アクチ ン線維（actin filament）を形成する。心筋細胞で は胎生期には平滑筋 $\alpha$-アクチンや骨格筋 $\alpha$-アクチン が発現するが, 生後 1 週以降になると心筋 $\alpha$-アクチ ンの割合が増加していく. 圧負荷や容量負荷で心肥 大が起こると平滑筋 $\alpha$-アクチンが再び増加する.

(3)トロポミオシン (tropomyosin): 2 本の $\alpha$ ヘリクッ 又構造の蛋白質で, 2 本鎖アクチン線維の溝の部分 に位置し, $\mathrm{Ca} 2^{+}$非存在下（拡張期）においてアク チンーミオシン結合部位をマスクする.

(4)トロポニン (troponin) 複合体 : トロポニンはトロ ポニン $\mathrm{C}$, トロポニン $\mathrm{I}$, トロポニン $\mathrm{T}$ より構成さ れる複合体である. $\mathrm{Ca} 2^{+}$に感受性があり, 心筋の 収縮力を調節する働きをもつ.

・トロポニン $\mathrm{C}: \mathrm{Ca} 2^{+}$結合サブユニットをもつ. 弛 緩期には $\mathrm{Mg} 2^{+}$が結合するが, $\mathrm{Ca}^{+}{ }^{+}$が結合すると 心筋細胞の収縮が開始する.

・トロポニン I : アクチンに結合する. トロポニンの 抑制系ユニットである。
・トロポニン $\mathrm{T}$ ：トロポニン複合体とトロポミオシン を結合する。

$\mathrm{Ca} 2^{+}$非存在下ではトロポニン複合体は密着し合 い, トロポニン I はアクチンと結合してアクチンーミ オシン結合部位がトロポミオシンによりブロックされ る. $\mathrm{Ca} 2^{+}$存在下では, $\mathrm{Ca} 2^{+}$が結合したトロポニン C に構造変化が起こり, トロポニン I-アクチン間の結 合を解離し, トロポミオシンはアクチンの溝から移動 してアクチンーミオシン結合部位が解放されるように なり，収縮が開始する。

\section{2. サルコメア骨格蛋白}

(1) myosin binding protein-C (MBP-C): 隣り合うミオ シン線維を束ね, サルコメアの構造維持に寄与する.

(2) titin：Z帯から M 帯まで伸びる分子量 2,700,000, 長 さ約 $1.0 \mu \mathrm{m}$ の巨大ならせん状の弾性性の蛋白質で, ミオシンを支持するとともにサルコメアの弾性を担う.

(3) nebulette : アクチン結合部位を多数もち, 弾性は ないがアクチン線維を支持する.

\section{3. 細胞骨格蛋白}

アクチンやミオシンは $\alpha$-アクチニン $(\alpha$-actinin $)$ とデスミン (desmin) を主成分とする Z 帯に強固に 
固定されている.さらに Z帯は細胞膜に接する部分 でコスタメア（costamere）と呼ばれる特殊な構造 （接着斑）を形成する。コスタメアにはビンキュリン (vinculin), ターリン（talin）などの細胞骨格蛋白と ともに, focal adhesion kinase (FAK) や muscle LIM protein などのシグナル伝達蛋白質が存在する. Z 带 は細胞一基質接着因子であるインテグリン（integrin） を介して, 細胞外のコラーゲン, フィブロネクチン, ラミニンなどの基質（extracellular matrix）と接着 し, 筋原線維の収縮を隣り合う細胞に伝えるととも に, 細胞外の機械的なストレスを核に伝えるシグナル 伝達の場にもなっている．また心筋細胞の両端におい ては Z 帯は介在板（intercalated disk）を形成し, 細 胞一細胞接着因子であるカドヘリン (cadherin) やカ テニン（catenin）を介して隣り合う心筋細胞同士を 強固に接着している.

\section{III. 一次性心筋症}

\section{1. 肥大型心筋症}

\section{1) 概念}

肥大型心筋症は, 主に心室中隔を中心とした心室壁 の肥厚により, 拡張能の低下をきたす疾患である.心 室の収縮性はむしろ過度に克進している場合が多く, 左室流出路閉塞が見られることがある. 無症状に経過 する場合も多く, 罹患率は一般人口の $0.2 \%$ と高頻度 の報告がある ${ }^{1)}$. 小児期から若年成人期発症例では, 乳児期に 1 つのピークがあり, それ以降は 10 歳から 25 歳で発症するものが多い. 乳児期の肥大型心筋症 は, Noonan 症候群など全身疾患や症候群に合併する ものが多く, 小児期以降の発症例は家族性の肥大型心 筋症が多い。肥大型心筋症は若年者の突然死の原因と して最も重要な疾患である。早期には拡張不全による 心不全をきたすが, 経過とともに左室の拡張と収縮性 の低下をきたす場合がある. 組織学的には, 心筋細胞 の不均一な肥大と錯綜配列を特徵としている。室中 隔の肥大が著明な例が多く (非対称性中隔肥大), 著 しい症例では左室流出路狭窄をきたす（閉塞性肥大型 心筋症)。 心筋肥大により, 心室内腔は狭小化し, 拡 張障害を示す. また, 心拍出量の低下は, 失神や突然 死をきたすことがあり, 心筋虚血のため, 胸痛を生じ ることもある. 収縮力は, 正常に保たれている例が多 いが，次第に心拡大と収縮力の低下をきたし心不全を 生じる例（拡張相肥大型心筋症）は，予後不良である。

\section{2) 遺伝学的要因}

肥大型心筋症は主にサルコメアの疾患であり, 心
筋の収縮や調節を行う 8 つのサルコメア関連遺伝子 の異常がコホート研究の $60 \%$ に扔いて認められる (Table 2). 細胞レベルでは, 肥大型心筋症の変異は マイオフィラメントの感受性の増加やカルシウムの結 合性の増加, actin-activated ATPaseの活性の増加が 見られる. 動力の発生において, 肥大型心筋症の遺伝 子変異はエネルギー非効率化とエネルギー消費の増大 をもたらす。拡張型心筋症や不整脈源性右室異形成症 と同じように, 遺伝形式は常染色体顕性遺伝であり, 座と対立遺伝子の異質性 (locus and allelic heterogeneity）が認められる。肥大型心筋症に最も変異が見 られる遺伝子は $M Y H 7$ と $M Y B P C 3$ であり，2つで $50 \%$ を占める. 残りのサルコメア遺伝子の TNNT2, TNNI3, TPM1, ACTC1, MYL3, MYL2 で 10\%を占め る. 近年, 複合へテロ接合性や多因子遺伝病が肥大型 心筋症で 2.5〜 5\%の割合で見いだされるようになって きている。このような患者は若年発症でより重症であ り，心筋切除術や ICD 埋め込み術の割合が高い。病 原遺伝子に加えて, 遺伝子的要素, エピジェネティッ クな因子, 環境因子の修飾が肥大型心筋症の病型には 重要である.

\section{(1)サルコメア関連遺伝子}

MYBPC3 の遺伝子変異は, 肥大型心筋症では最も よく認められる遺伝子変異である. MYBPC3 は, ミ オシンを介した収縮の安定化や調節を行っていると 考えられている.ほかの肥大型心筋症の遺伝子変異 ではミスセンス変異によりアミノ酸が置換されるのと は対照的に, MYBPC3の多くはナンセンス变異かフ レームシフトであり, 不完全な蛋白が産生される ${ }^{2)}$.

MYBPC 3 の遺伝子変異は浸透率が低く, 発症が晚発 性であり，生存率は良いが，いったん発症するとリス クは他の肥大型心筋症と同等である ${ }^{3,4)}$.

MYH7 の遺伝子変異は肥大型心筋症全体の原因の $20 \%$ を占める. 一般的に, $M Y H 7$ 遺伝子変異は, 著 明な肥大を伴う, 比較的若年に発症する典型的な肥大 型心筋症と関連がある ${ }^{5)}$. MYH7 の遺伝子変異は肥 大型心筋症だけに限らず, 拡張型心筋症や心筋緻密化 障害，ミオパチーにも見られる。

thin filament のトロポニン複合蛋白をコードする TNNT2 とTNNI3 遺伝子にも病型の多様性があり, 肥大型心筋症, 拡張型心筋症, 拘束型心筋症, 心筋緻 密化障害にも認められる ${ }^{6}$. 他の多くのサルコメア蛋 白のように, TNNT2 変異はしばしば比較的軽症の拡 張型心筋症を示すが心臓突然死のリスクは高い. トロ ポニンの遺伝子変異により thin filament 上のカルシ ウム結合能結合能は肥大型心筋症の場合は増強し, 拡 
Table 2 Causative genes for hypertrophic cardiomyopathy

\begin{tabular}{|c|c|c|c|c|}
\hline Gene & Protein & Locus & Inheritance & Prevalence (\%) \\
\hline \multicolumn{5}{|l|}{ Sarcomere } \\
\hline MYH7 & $\beta$-Myosin heavy chain & $14 q 11.2-q 12$ & $A D$ & $25-40$ \\
\hline MYH6 & a-Myosin heavy chain & $14 q 11.2-q 12$ & $A D$ & $<1$ \\
\hline MYL2 & Regulatory myosin light chain & $12 q 23-q 24.3$ & $A D$ & $<1$ \\
\hline$M Y L 3$ & Essential myosin light chain & $3 p 21.2-p 21.3$ & $A D$ & $<1$ \\
\hline TNNT2 & Cardiac troponin $\mathrm{T}$ & $1 q 32$ & $A D$ & $3-5$ \\
\hline TNN/3 & Cardiac troponin I & $19 \mathrm{p} 13.4$ & $A D$ & $1-5$ \\
\hline TPM1 & $a$-Tropomyosin & $15 q 22.1$ & $A D$ & $1-5$ \\
\hline ACTC & $a$-Cardiac actin & $15 q 14$ & $A D$ & $<1$ \\
\hline TNNC1 & Cardiac troponin $\mathrm{C}$ & $3 p 21.1$ & $A D$ & $<1$ \\
\hline МYВРCЗ & Cardiac myosin-binding protein C & $11 \mathrm{p} 11.2$ & $A D$ & $25-40$ \\
\hline$\pi N$ & Titin & $2 q 31$ & $A D$ & $<1$ \\
\hline \multicolumn{5}{|l|}{ Z-disc } \\
\hline ACTN2 & a-Actinin 2 & $1 q 42-q 43$ & $A D$ & $<1$ \\
\hline$A N K R D 1$ & Cardiac ankyrin repeat protein & $10 q 23.31$ & $A D$ & $<1$ \\
\hline CSPR3 & Muscle LIM protein & $11 \mathrm{p} 15.1$ & $A D$ & $<1$ \\
\hline$\angle D B 3$ & LIM binding domain 3 & $10 q 22.2-q 23.3$ & $A D$ & $1-5$ \\
\hline MYOZ2 & Myozenin 2 & $4 q 26-q 27$ & $A D$ & $<1$ \\
\hline TCAP & Telethonin & $17 q 12-q 21.1$ & $A D$ & $<1$ \\
\hline$V C L$ & Vinculin/metavinculin & $10 q 22.1-q 23$ & $A D$ & $<1$ \\
\hline \multicolumn{5}{|c|}{ Calcium-handling } \\
\hline JPH2 & Junctophilin 2 & $20 q 13.12$ & $A D$ & $<1$ \\
\hline$P L N$ & Phospholamban & $6 q 22.1$ & $A D$ & $<1$ \\
\hline
\end{tabular}

張型心筋症の場合は減弱する ${ }^{7)}$.

肥大型心筋症の他の 4 つの TPM1, ACTC1, MYL2, MYL3 遺伝子変異は良性である.TPM1 の遺伝子変異 は拡張型心筋症や肥大型心筋症を引き起こす 8,9 . 肥 大型心筋症の遺伝子変異はほとんどが $\mathrm{N}$ 末端のドメ インやトロポニン $\mathrm{T}$ 結合部位に集積し thin filament のカルシウム感受性を増加させる.

\section{2. 拡張型心筋症}

\section{1) 概念}

拡張型心筋症は, 左室の拡張と収縮性の低下が特徴 である。筋の変性, 萎縮や線維化により, 心収縮力 が低下し，心拍出量が低下する，小児期では，いずれ の年齢にも認められる. 原因疾患にかかわらず， 5 年 生存率は $50 \%$ と不良である ${ }^{10,11)}$. 家族性, 心筋炎後 など原因は様々である. 交感神経系の充進により, 後 負荷は増大し, 心筋酸素消費量が増大する. TNF- $\alpha$ な ど種々のサイトカインが血中に増加し, 心筋障害を助 長する. 死亡原因は, ポンプ機能の低下による心不全 か, 不整脈による突然死である. 近年は, ACE 阻害 薬や $\beta$ 遮断薬など内科的治療に加えて, 植込み型除細 動器や心室補助装置の普及により予後はいくぶん改善 されている.

\section{2）遺伝学的要因}

拡張型心筋症の約 $30 \sim 40 \%$ に家族性があり，小児 期ではミトコンドリア遺伝や常染色体顕性遺伝形式を とるものが主体であり，X 連鎖性や常染色体潜性遺伝 形式はまれである.

家族性拡張型心筋症については, 50 以上の原因遺 伝子が示唆されている（Table 3)。家族性拡張型心 筋症の 30〜35\%に遺伝子変異が見いだされており, TTN, LMNA, MYH7, TNNT2が主要な遺伝子である. TTN の遺伝子変異が最もよく見いだされており, 家族性拡張型心筋症の $25 \%$, 弧発性拡張型心筋症の $18 \%$ で報告されている ${ }^{12)}$. 伝導障害を伴う拡張型心筋 症の場合, LMNA 遺伝子変異が $1 / 3$ に認められる ${ }^{12)}$.

伝導障害を伴う拡張型心筋症では, lamin A/C (LMNA）遺伝子変異が認められる ${ }^{13)}$. LMNA 変異 により引き起こされる拡張型心筋症は, 初期には房室 ブロックなどの伝導障害が認められること，心蔵突然 死のリスクが高いことが特徴的である ${ }^{14)}$. 一般的に 伝導障害は拡張型心筋症の病勢に伴い進行するが，骨 格筋の障害との関連は症例ごとに異なる ${ }^{13)}$.

骨格筋異常を伴う拡張型心筋症は, ジストロフィ ンの遺伝子変異が原因であることが多い ${ }^{15)}$. ジスト ロフィン遺伝子は Duchenneや Becker muscular dystrophy（DMD/BMD）の責任遺伝子でもある. DMD 
Table 3 Causative genes for dilated cardiomyopathy

\begin{tabular}{|c|c|c|c|c|c|}
\hline Gene & Protein & Locus & Inheritance & Prevalnece & Phenotype \\
\hline \multicolumn{6}{|c|}{ Sarcomere } \\
\hline MYH7 & Myosin heavy chain 7 & $14 q 12$ & $A D$ & $4 \%$ & $\mathrm{HCM} / \mathrm{DCM} / \mathrm{RCM} / \mathrm{LVNC}$ \\
\hline MYH6 & Myosin heavy chain 6 & $14 q 12$ & $A D$ & & $\mathrm{HCM} / \mathrm{DCM}$ \\
\hline МУВРСЗ & Myosin binding protein $\mathrm{C}$, cardiac & $11 \mathrm{p} 11.2$ & $A D$ & $2 \%$ & HCM/DCM/LVNC \\
\hline TNNT2 & Troponin T2, cardiac type & $1 q 32$ & $A D$ & $2 \%$ & $\mathrm{HCM} / \mathrm{DCM} / \mathrm{RCM} / \mathrm{LVNC}$ \\
\hline TNNC1 & Troponin C1, slow skeletal and cardiac type & $3 p 21.1$ & $A D$ & & $\mathrm{HCM} / \mathrm{DCM}$ \\
\hline TNN/3 & Troponin I3, cardiac type & $19 q 13.4$ & $A D, A R$ & & $\mathrm{HCM} / \mathrm{DCM} / \mathrm{RCM}$ \\
\hline TPM1 & Tropomyosin 1 (alpha) & $15 q 22.1$ & $A D$ & & $\mathrm{HCM} / \mathrm{DCM} / \mathrm{RCM} / \mathrm{LVNC}$ \\
\hline ACTC1 & Actin, alpha, cardiac muscle 1 & $15 q 14$ & $A D$ & & HCM/DCM/LVNC \\
\hline$T T N$ & Titin & $2 q 31$ & $A D$ & $20-25 \%$ & HCM/DCM/ARVC \\
\hline \multicolumn{6}{|l|}{ Z-disc } \\
\hline$B A G 3$ & BCL2 associated athanogene 3 & $10 q 25.2-q 26.2$ & $A D$ & $2 \%$ & DCM \\
\hline CRYAB & Crystallin alpha $B$ & $11 q 23.1$ & $A D$ & & $\mathrm{DCM} / \mathrm{HCM}$ \\
\hline FHL2 & FHL2 four and a half LIM domains 2 & $2 q 12.2$ & $A D$ & & \\
\hline MURC & Muscle related coiled-coil protein & $9 q 31.1$ & $A D$ & & $\mathrm{DCM}$ \\
\hline MYPN & Myopalladin & $10 q 21.3$ & $A D$ & $2 \%$ & $\mathrm{DCM} / \mathrm{HCM} / \mathrm{RCM}$ \\
\hline$N E B L$ & Nebulette & $10 \mathrm{p} 12$ & $A D$ & & DCM/EFE \\
\hline NEXN & Nexilin F-actin binding protein & $1 \mathrm{p} 31.1$ & $A D$ & & $\mathrm{DCM} / \mathrm{HCM}$ \\
\hline \multicolumn{6}{|c|}{ Cell structure } \\
\hline ACTN2 & Actinin alpha 2 & $1 q 42-q 43$ & $A D$ & & DCM \\
\hline CSRP3 & Cysteine and glycine rich protein 3 & $11 \mathrm{p} 15.1$ & $A D$ & & $\mathrm{HCM} / \mathrm{DCM}$ \\
\hline$D M D$ & Dystrophin & Xp21.2 & $\mathrm{XR}$ & & DCM \\
\hline FKTN & Fukutin & $9 q 31.2$ & AR & & DCM \\
\hline$J U P$ & Junction plakoglobin & $17 q 21$ & $A R, A D$ & & DCM/ARVC \\
\hline$\angle D B 3$ & LIM domain binding 3 & $10 q 22.3-q 23.2$ & $A D$ & & DCM/LVNC \\
\hline$S G C D$ & Sarcoglycan delta & $5 q 33.3$ & $A D$ & & $\mathrm{DCM}$ \\
\hline TCAP & Titin-cap & $17 q 12$ & $A D$ & & $\mathrm{HCM} / \mathrm{DCM}$ \\
\hline$V C L$ & Vinculin & $10 q 22-q 23$ & $A D$ & & $\mathrm{HCM} / \mathrm{DCM}$ \\
\hline \multicolumn{6}{|c|}{ Desmosome } \\
\hline$D E S$ & Desmin & $2 q 35$ & $A D$ & & $\mathrm{DCM} / \mathrm{RCM}$ \\
\hline$D S P$ & Desmoplakin & $6 p 24$ & AR & & DCM/ARVC/LVNC \\
\hline PLN & Phospholamban & $6 q 22.1$ & $A D$ & & DCM \\
\hline$E M D$ & Emerin & Xq28 & $\mathrm{XR}$ & & $\mathrm{DCM}$ \\
\hline LMNA & Lamin A/C & $1 q 22$ & $A D$ & $6 \%$ & DCM \\
\hline TMPO & Thymopoietin & $12 q 22$ & $A D$ & & DCM \\
\hline$A N K R D 1$ & Ankyrin repeat domain 1 & $10 q 23.31$ & $A D$ & & $\mathrm{HCM} / \mathrm{DCM}$ \\
\hline GATAD1 & GATA zinc finger domain containing 1 & $7 q 21-q 22$ & AR & & DCM \\
\hline RBM20 & RNA binding motif protein 20 & $10 q 25.2$ & $A D$ & $2 \%$ & DCM \\
\hline \multicolumn{6}{|l|}{ Others } \\
\hline ABCC9 & ATP binding cassette subfamily $C$ member 9 & $12 \mathrm{p} 12.1$ & $A D$ & $1 \%$ & DCM \\
\hline SCN5A & Sodium voltage-gated channel alpha subunit 5 & $3 p 21$ & $A D$ & $2 \%$ & $\mathrm{DCM}$ \\
\hline LAMA4 & Laminin subunit alpha 4 & $6 q 21$ & $A D$ & & DCM \\
\hline DOLK & Dolichol kinase & $9 q 34.11$ & AR & & $\mathrm{DCM}$ \\
\hline
\end{tabular}

や BMD は骨格筋疾患の多くを占め，いずれも小览期 あるいは若年成人で発症するが，ほとんどの症例は 25 歳までに拡張型心筋症を発症する。 ジストロフィ ンは細胞骨格蛋白であり，格子状のネットワークを形 成して，筋細胞を支持している，そして，サルコメア と筋細胞膜や細胞外基質との結合と収縮力の伝達にお いて，最も重要な役割を果たしている．さらに，NO 合成酵素と作用して, 細胞シグナル伝達にも関与して
いる ${ }^{16)}$ 。 ジストロフィンの $\mathrm{N}$ 末端はサルコメアのア クチンと結合し，C末端はジストログリカン，サルコ グリカン，シントロピン， ジストロブレビンなどのジ ストロフィン関連蛋白と結合している。さうに，これ らの蛋白は， $\alpha$-ジストログリカンを通じて，ラミニン （laminin）や細胞外基質と結びついている。これらジ ストロフィン関連蛋白の異常は，ジストロフィン同様 に骨格筋疾患や心筋症の原因となる。 


\section{3. 左室心筋緻密化障害}

\section{1) 概念}

左室心筋緻密化障害は, 心室壁の過剩な網目状の肉 柱形成と深い間隙を形態的特徴とし, WHO 分類では unclassified cardiomyopathy の 1 つとして分類されて いる ${ }^{3)}$. 典型例は, 新生児期に心不全のため死亡し, 心移植の対象になっている疾患である ${ }^{17)}$. 血行動態 の特徴は心収縮力の低下で, 左室の拡大を伴う例と, 伴わないものがある. 拘束型心筋症に類似した血行動 態を呈する症例も報告されている. 収縮力の低下して いる網目状の肉柱の間に, 血栓が形成されやすく, 他 の拡張型心筋症に比し, 脳や肺などの, 全身の血栓塞 栓症を合併する危険性が高い. 臨床像は無症状の症例 から, 高度の心機能障害を有し, 心移植の対象になっ ているものまであり, きわめて多彩である ${ }^{17-19)}$. 原 因は多岐にわたる.

\section{2) 遺伝学的要因}

弧発性と家族性の双方認められる. 本邦の全国調査 の結果では, 高率 (40\%) に家族例が認められ, X 連 鎖性のほか, 常染色体顕性遺伝形式, 常染色体潜性遺 伝形式，あるいはミトコンドリア遺伝子変異が疑われ る家系もあり, 遺伝的多様性が特徴である ${ }^{18)}$. TAZ, DTNA PDB3 などの多数の遺伝子変異が原因であ ることがわかっている (Table 4).

小児と成人の心筋緻密化障害では, 原因遺伝子にも 差が見られ, 成人では, サルコメア遺伝子変異が主体 で, TAZ, LDB3 などの小児で見られる遺伝子変異は, まれである. 単一遺伝子変異のほかにも, 染色体異 常, 筋疾患, ミトコンドリア筋症などの疾患に合併し て見られることがあり，原因は多岐にわたる ${ }^{25-30)}$. 近年, スペイン人の心筋緻密化障害の 2 家系から, 常 染色体顕性遺伝形式で MIB1 の遺伝子変異が認められ た. この MIB1 のノックアウトマウスでは, 心筋に著 明な肉柱化と緻密化障害が認められ, 心筋緻密化障害 と NOTCH1 シグナルとの関連が示唆されている ${ }^{31)}$.

\section{4. ミトコンドリア心筋症}

ミトコンドリア病は心筋症を合併する。 ミトコンド リア病の症状は様々で, 通常は多臟器に障害が見ら れ, 特に高容量の ATP を必要とする心蔵, 骨格筋, 神経が侵される. 典型的にはその変化は乳児や胎児期 に起こり, サルコメア遺伝子変異の心筋症に見られる ような代償期はない。ミトコンドリア心筋症は, 肥大 型心筋症様の病型がより一般的である. いくつかの全 身性のミトコンドリア病（ミトコンドリア脳筋症, MELAS, MERRF, Kearns-Sayr 症候群, Leigh 病など)
では, ミオパチー, 脳症, てんかん, 眼筋麻痺, 失調 症, 難聴といったミトコンドリア病の症状とともに, その特徴に含まれる.

ミトコンドリアの機能異常はミトコンドリアや核 の遺伝子変異により引き起こされる（Fig. 3). ミトコ ンドリア DNA の異常は heteroplasmy（1 細胞中にお ける変異ミトコンドリア DNA の混在）が特徴とされ る. 遺伝形式は母系である. 核の遺伝子変異に由来す るミトコンドリア病は様々な遺伝子形式を示し，典型 的には常染色体潜性遺伝やX染色体遺伝を示すこと が多い.

ミトコンドリア病の心筋症の頻度は 17～40\% と 様々で, 多くは肥大型心筋症である ${ }^{32-34)}$. 核蛋白を コードする SCO2 の遺伝子変異は, 乳児のミトコンド リア心筋症の原因としてょく知られている ${ }^{35)}$. SCO2 はシトクローム C 酸化酵素, 呼吸鎖の複合体 IV の一 部であり，新生児期に肥大型心筋症や脳症や筋緊張低 下を発症する ${ }^{36)}$.ほかには，ミトコンドリア心筋症 を引き起こす核蛋白遺伝子は，ミトコンドリアの呼 吸鎖を構成する遺伝子（NDUFS2, NDUFV2, SDHA, SCO2, COX15，TMEM70等)，ミトコンドリア DNA の翻訳に関連する遺伝子 (MRPS22), ATP 合成に関 連する遺伝子（SLC25A3）, リン脂質のリモデリング に関連する遺伝子（TAZ）がある。 TMEM70 はミト コンドリア複合体 Vの欠損から ATP 合成を減少さ せ，筋緊張低下，乳酸アシドーシス，3-methylaciduria を合併し ${ }^{37)}$, 心筋症としては, 肥大型心筋症, X 連鎖性心内膜線維弾性症，X連鎖性致死的拡張型心筋 症，家族性の心筋緻密化障害を引き起こす。室性不 整脈が特徴的である.

Barth 症候群は, X 連鎖性の心筋骨格筋疾患であ り, 成長障害好中球減少，3-メチルグルタコンサン 尿が認められる. 電子顕微鏡では, 筋細胞のミトコン ドリアの機能異常が認められる。一般的には, 乳児早 期に発症し，心不全や敗血症で死亡するが，乳児期以 降では, 拡張型心筋症は存在するが比較的安定した臨 床経過であることが多い. Barth 症候群の責任遺伝子 は TAZ 遺伝子であり, この遺伝子変異のためミトコ ンドリア膜上のカルジオリピンの欠乏が引き起こされ る. TAZ 遺伝子変異は, 拡張型心筋症, 心内膜線維 弾性症や心筋緻密化障害など，多彩な心筋症を発症す るが, Barth 症候群の臨床症状を伴う場合も伴わない 場合もある ${ }^{38)}$.

ミトコンドリアゲノムは $16.6 \mathrm{~kb}$ であり，そのなか で，全身性の疾患の原因とされる 250 以上のミトコ ンドリア DNAの遺伝子変異が報告されている ${ }^{39)}$. 
Table 4 Causative genes for left ventricular noncompaction

\begin{tabular}{|c|c|c|c|}
\hline Gene & Protein & Locus & Inheritance \\
\hline \multicolumn{4}{|c|}{ Genes associated with cardiomyopathies and or CHD and LVNC } \\
\hline MYH7 & Beta-myosin heavy chain 7 & $14 q 12$ & $A D$ \\
\hline МYВРCЗ & Myosin-binding protein C & $11 \mathrm{p} 11.2$ & $A D$ \\
\hline TNNT2 & Cardiac troponin $\mathrm{T} 2$ & $1 q 32$ & $A D$ \\
\hline TPM1 & Tropomyosin 1 & $15 q 22.1$ & $A D$ \\
\hline ACTC1 & Cardiac alpha-actin & $15 q 14$ & $A D$ \\
\hline ACTN2 & Alpha-actinin 2 & $1 q 42-q 43$ & $A D$ \\
\hline DTNA & Dystrobrevin & $18 q 12.1$ & $A D$ \\
\hline$\angle D B 3$ & Z-Band alternatively spliced PDZ motif-containing protein & $10 q 22.3-q 23.2$ & $A D$ \\
\hline$D M P K$ & Dystrophia myotonica protein kinase & $19 q 13.32$ & $A D$ \\
\hline$D S P$ & Desmoplakin & $6 \mathrm{p} 24$ & $A D$ \\
\hline PKP2 & Plakophilin 2 & $12 \mathrm{p} 11.21$ & AR \\
\hline$R Y R 2$ & RYR2 & $1 q 43$ & $A D$ \\
\hline LMNA & Lamin AC & $1 q 22$ & $A D$ \\
\hline MIB1 & Mindbomb, homolog of, Drosophila & $18 q 11.2$ & $A D$ \\
\hline PRDM16 & PR domain protein 16 & $1 \mathrm{p} 36.32$ & $A D$ \\
\hline TBX20 & T-box20 & $7 p 14.2$ & $A D$ \\
\hline$A B C C 9$ & ATP-binding cassette, subfamily $\mathrm{C}$ members & $12 \mathrm{p} 12.1$ & $A D$ \\
\hline CASQ2 & Calsequestrin 2 & $1 \mathrm{p} 13.1$ & AR \\
\hline HCN4 & Hyperpolarization-activated cyclic nucleotide-gated potassium channel 4 & $15 q 24.1$ & $A D$ \\
\hline SCN5A & Sodium channel, voltage-gated, type $V$, alpha subunit & $3 p 21$ & $A D$ \\
\hline PLEKHM2 & Pleckstrin homology domain-containing protein, family M, member 2 & $1 \mathrm{p} 36.21$ & $A D$ \\
\hline \multicolumn{4}{|c|}{ Monogenic syndromes with major extracardiac traits and cardiac involvement including LVNC } \\
\hline ARFGEF2 & ADP-ribosylation factor guanine nucleotide-exchange factor 2 & $20 q 13.13$ & AR \\
\hline$M L Y C D$ & Malonyl-coenzyme A decarboxylase deficiency & $16 q 23.3$ & AR \\
\hline MMACHC & Cobalamin C deficiency & $1 \mathrm{p} 34.1$ & AR \\
\hline NNT & Nicotinamide nucleotide transhydrogenase & $5 p 12$ & AR \\
\hline NSD1 & Nuclear receptor binding SET domain protein1 & $5 q 35.3$ & Isolated type \\
\hline RSK2 & Ribosomal S6 kinase 2 & $\mathrm{Xp22.12}$ & XLD \\
\hline YWHAE (14-3-3ع) & Monooxygenase activation protein, epsilon isoform & $17 p 13.3$ & $A D$ \\
\hline
\end{tabular}

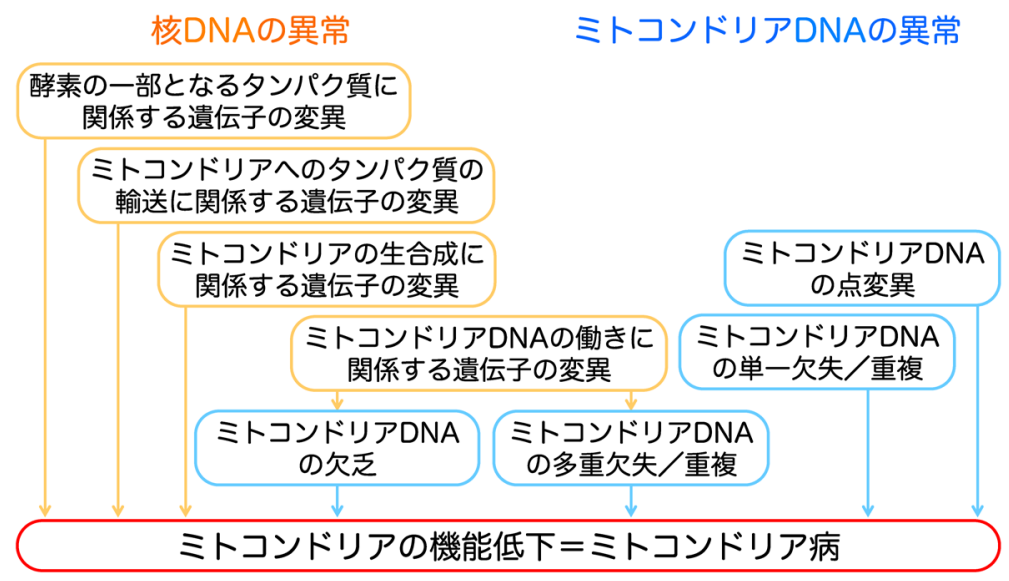

Fig. 3 Causative genes for mitochondrial cardiomyopathy

MTTL1 の m.3243A > G の変異は MELAS 患者に認め られ, 脳症, 低身長, 梗塞様のエピソード, けいれん, 乳酸アシドーシス，半盲を合併する. MELAS 患者の 心筋症は $40 \%$ に認められ，心機能低下を伴った対称 性の肥大をきたす ${ }^{40)}$. MERRF の患者は 80～90\%の
割合で肥大型心筋症もしくは拡張型心筋症を合併す $3^{41)}$. MTTIの変異は肥大型心筋症および拡張型心 筋症を発症する ${ }^{42)}$. MTTG の変異は, 肥大型心筋症 を発症する ${ }^{43)}$. 


\section{IV. 二次性心筋症}

種々の代謝疾患は，乳幼児発症の心筋症を合併す る. 代謝疾患は心臓への蓄積もしくは浸潤する疾患, エネルギー代謝異常症, 心毒性のある代謝産物を産生 する疾患に分類される ${ }^{44)}$.

Pompe 病は, グリコーゲンを分解するリソゾーム 酵素である $G A A$ の遺伝子変異による, acid $\alpha$-glucosidase の欠損症である. 肥大型心筋症とミオパチーを 主症状とする．乳児型扔よび遅発型（小览型・成人 型）に分類され，乳児型は肥大型心筋症により，遅発 型は呼吸不全により生命が脅かされる. Pompe 病に 対し酵素補充療法が導入され，心筋肥厚が改善するた め, 乳児型の生命予後が改善されてきている.

Fabry 病の原因である GLA の遺伝子変異は，全身 性の $\mathrm{X}$ 連鎖性のライソゾームの蓄積障害を引き起こ し, 心筋症，不整脈，腎障害，肢端触覚異常や被角血 管腫，毛細血管拡張症といった皮膚症状，発汗低下， 角膜混濁や脳血管障害を特徵とする。 Fabry 病はライ ソゾームの hydrolase $\alpha$-galactosidase A の欠損や久乏 により, glycosphingolipid が蓄積することが原因で ある．典型的には男性に認められるが，まれに女性患 者にも認められる. GLA 変異は肥大型心筋症を有し た家系の 3\%に認められた ${ }^{45)}$. Fabry 病は，心筋症が 唯一の症状であり, 酵素補充療法により治療が可能で ある.

PRKAG2 の遺伝子変異は, グリコーゲンの蓄積 や心筋細胞の錯綜配列により, 常染色体顕性遺伝の 形式で, 家族性の肥大型心筋症を引き起こす ${ }^{46)}$.

PRKAG2 の遺伝子変異は, 心電図上, 心室の早期興 奮, 徐脈傾向, 進行性の伝導障害を伴った WPW 症 候群も合併する。

Danon 病は，X連鎖性の肥大型心筋症であり，ミ オパチー, 知的障害を伴う。 LAMP2 の遺伝子変異に より，ライソゾームの膜レセプターを介したオート ファジーが原因とされている。 Danon 病は，心室の 早期興奮, 不整脈, 拡張型心筋症へと進行する著明な 心筋肥大を特徵とし，通常の肥大型心筋症より予後不 良であり，成人期早期にしばしば心移植が必要とな る.Danon 病は女性においてより重症である.

\section{最後に}

次世代シーケンサーの登場により，遺伝学的要因が 徐々に明らかにされてきているが，遺伝子・表現型相 関が明らかであるのはごく一部にすぎない，また，心
筋症の診療において，遺伝子診断が行われているのは 少数の症例に限られる. また，今後の心筋症研究の発 展のために，また，診療において遺伝性心筋症の原因 探索のために，大きな家系の集積および正確な臨床情 報収集が不可欠である.

利益相反

本論文について，開示すべき利益相反（COI）はない。

\section{引用文献}

1) Maron BJ: Hypertrophic cardiomyopathy. Lancet 1997; 350: $127-133$

2) Marston S, Copeland O, Jacques A, et al: Evidence from human myectomy samples that MYBPC3 mutations cause hypertrophic cardiomyopathy through haploinsufficiency. Circ Res 2009; 105: 219-222

3) Niimura $H$, Bachinski LL, Sangwatanaroj S, et al: Mutations in the gene for cardiac myosin-binding protein $\mathrm{C}$ and late-onset familial hypertrophic cardiomyopathy. $\mathrm{N}$ Engl J Med 1998; 338: 1248-1257

4) Charron P, Dubourg O, Desnos M, et al: Clinical features and prognostic implications of familial hypertrophic cardiomyopathy related to the cardiac myosin-binding protein C gene. Circulation 1998; 97: 2230-2236

5) Watkins $\mathrm{H}$, Rosenzweig A, Hwang DS, et al: Characteristics and prognostic implications of myosin missense mutations in familial hypertrophic cardiomyopathy. $\mathrm{N}$ Engl J Med 1992; 326: 1108-1114

6) Kimura A, Harada H, Park JE, et al: Mutations in the cardiac troponin I gene associated with hypertrophic cardiomyopathy. Nat Genet 1997; 16: 379-382

7) Robinson P, Griffiths PJ, Watkins $\mathrm{H}$, et al: Dilated and hypertrophic cardiomyopathy mutations in troponin and alpha-tropomyosin have opposing effects on the calcium affinity of cardiac thin filaments. Circ Res 2007; 101: 1266-1273

8) Thierfelder L, Watkins H, MacRae C, et al: Alpha-tropomyosin and cardiac troponin $\mathrm{T}$ mutations cause familial hypertrophic cardiomyopathy: A disease of the sarcomere. Cell 1994; 77: 701-712

9) Watkins H, McKenna WJ, Thierfelder L, et al: Mutations in the genes for cardiac troponin $\mathrm{T}$ and alpha-tropomyosin in hypertrophic cardiomyopathy. N Engl J Med 1995; 332: 1058-1064

10) Matitiau A, Perez-Atayde A, Sanders SP, et al: Infantile dilated cardiomyopathy. Relation of outcome to left ventricular mechanics, hemodynamics, and histology at the time of presentation. Circulation 1994; 90: 1310-1318

11) Lipshultz SE, Sleeper LA, Towbin JA, et al: The incidence of pediatric cardiomyopathy in two regions of the United States. N Engl J Med 2003; 348: 1647-1655

12) Herman DS, Lam L, Taylor MR, et al: Truncations of titin causing dilated cardiomyopathy. N Engl J Med 2012; 366: 619-628

13) Brodsky GL, Muntoni F, Miocic S, et al: Lamin A/C gene mutation associated with dilated cardiomyopathy with variable skeletal muscle involvement. Circulation 2000; 


\section{1: $473-476$}

14) Fatkin D, Roy P, Morgan JJ, et al: Percutaneous balloon mitral valvotomy with the Inoue single-balloon catheter: Commissural morphology as a determinant of outcome. J Am Coll Cardiol 1993; 21: 390-397

15) Hoffman EP, Brown RH Jr., Kunkel LM: Dystrophin: the protein product of the Duchenne muscular dystrophy locus. Cell 1987; 51: 919-928

16) Chang WJ, Iannaccone ST, Lau KS, et al: Neuronal nitric oxide synthase and dystrophin-deficient muscular dystrophy. Proc Natl Acad Sci USA 1996; 93: 9142-9147

17) Chin TK, Perloff JK, Williams RG, et al: Isolated noncompaction of left ventricular myocardium: A study of eight cases. Circulation 1990; 82: 507-513

18) Ichida $F$, Hamamichi $Y$, Miyawaki $T$, et al: Clinical features of isolated noncompaction of the ventricular myocardium: Long-term clinical course, hemodynamic properties, and genetic background. J Am Coll Cardiol 1999; 34: $233-240$

19) Pignatelli RH, McMahon CJ, Dreyer WJ, et al: Clinical characterization of left ventricular noncompaction in children: A relatively common form of cardiomyopathy. Circulation 2003; 108: 2672-2678

20) Hoedemaekers YM, Caliskan $K$, Michels $M$, et al: The importance of genetic counseling, DNA diagnostics, and cardiologic family screening in left ventricular noncompaction cardiomyopathy. Circ Cardiovasc Genet 2010; 3: 232-239

21) Klaassen S, Probst S, Oechslin E, et al: Mutations in sarcomere protein genes in left ventricular noncompaction. Circulation 2008; 117: 2893-2901

22) Dellefave LM, Pytel P, Mewborn S, et al: Sarcomere mutations in cardiomyopathy with left ventricular hypertrabeculation. Circ Cardiovasc Genet 2009; 2: 442-449

23) Budde BS, Binner P, Waldmuller S, et al: Noncompaction of the ventricular myocardium is associated with a de novo mutation in the beta-myosin heavy chain gene. PLoS One 2007; 2: e1362

24) Kelley-Hedgepeth A, Towbin JA, Maron MS: Images in cardiovascular medicine. Overlapping phenotypes: Left ventricular noncompaction and hypertrophic cardiomyopathy. Circulation 2009; 119: e588-e589

25) Wong JA, Bofinger MK: Noncompaction of the ventricular myocardium in Melnick-Needles syndrome. Am J Med Genet 1997; 71: 72-75

26) Mandel K, Grunebaum E, Benson L: Noncompaction of the myocardium associated with Roifman syndrome. Cardiol Young 2001; 11: 240-243

27) Corrado G, Checcarelli N, Santarone M, et al: Left ventricular hypertrabeculation/noncompaction with PMP22 duplication-based Charcot-Marie-Tooth disease type 1A. Cardiology 2006; 105: 142-145

28) McMahon CJ, Chang AC, Pignatelli RH, et al: Left ventricular noncompaction cardiomyopathy in association with trisomy 13. Pediatr Cardiol 2005; 26: 477-479

29) Kanemoto N, Horigome H, Nakayama J, et al: Interstitial 1q43-q43 deletion with left ventricular noncompaction myocardium. Eur J Med Genet 2006; 49: 247-253

30) Pauli RM, Scheib-Wixted S, Cripe L, et al: Ventricular noncompaction and distal chromosome $5 \mathrm{q}$ deletion. Am J Med Genet 1999; 85: 419-423
31) Luxan G, Casanova JC, Martinez-Poveda B, et al: Mutations in the NOTCH pathway regulator MIB1 cause left ventricular noncompaction cardiomyopathy. Nat Med 2013; 19: 193-201

32) Holmgren D, Wahlander H, Eriksson BO, et al: Cardiomyopathy in children with mitochondrial disease; clinical course and cardiological findings. Eur Heart J 2003; 24: 280-288

33) Scaglia F, Towbin JA, Craigen WJ, et al: Clinical spectrum, morbidity, and mortality in 113 pediatric patients with mitochondrial disease. Pediatrics 2004; 114: 925-931

34) Yaplito-Lee J, Weintraub R, Jamsen K, et al: Cardiac manifestations in oxidative phosphorylation disorders of childhood. J Pediatr 2007; 150: 407-411

35) Schiff M, Ogier de Baulny H, Lombes A: Neonatal cardiomyopathies and metabolic crises due to oxidative phosphorylation defects. Semin Fetal Neonatal Med 2011; 16: 216-221

36) Papadopoulou LC, Sue CM, Davidson MM, et al: Fatal infantile cardioencephalomyopathy with COX deficiency and mutations in SCO2, a COX assembly gene. Nat Genet 1999; 23: 333-337

37) Cizkova A, Stranecky V, Mayr JA, et al: TMEM70 mutations cause isolated ATP synthase deficiency and neonatal mitochondrial encephalocardiomyopathy. Nat Genet 2008; 40: 1288-1290

38) D'Adamo P, Fassone L, Gedeon A, et al: The X-linked gene G4.5 is responsible for different infantile dilated cardiomyopathies. Am J Hum Genet 1997; 61: 862-867

39) Bates MG, Bourke JP, Giordano C, et al: Cardiac involvement in mitochondrial DNA disease: Clinical spectrum, diagnosis, and management. Eur Heart J 2012; 33: 30233033

40) Fayssoil A: Heart diseases in mitochondrial encephalomyopathy, lactic acidosis, and stroke syndrome. Congest Heart Fail 2009; 15: 284-287

41) Anan R, Nakagawa M, Miyata M, et al: Cardiac involvement in mitochondrial diseases. A study on 17 patients with documented mitochondrial DNA defects. Circulation 1995; 91: 955-961

42) Tanaka M, Obayashi T, Yoneda M, et al: Mitochondrial DNA mutations in cardiomyopathy: Combination of replacements yielding cysteine residues and tRNA mutations. Muscle Nerve Suppl 1995; 3 S14: S165-S169

43) Merante F, Tein I, Benson L, et al: Maternally inherited hypertrophic cardiomyopathy due to a novel T-to-C transition at nucleotide 9997 in the mitochondrial tRNA(glycine) gene. Am J Hum Genet 1994; 55: 437-446

44) Schwartz ML, Cox GF, Lin AE, et al: Clinical approach to genetic cardiomyopathy in children. Circulation 1996; 94: 2021-2038

45) Havndrup O, Christiansen M, Stoevring B, et al: Fabry disease mimicking hypertrophic cardiomyopathy: Genetic screening needed for establishing the diagnosis in women. Eur J Heart Fail 2010; 12: 535-540

46) Blair E, Redwood C, Ashrafian $\mathrm{H}$, et al: Mutations in the gamma(2) subunit of AMP-activated protein kinase cause familial hypertrophic cardiomyopathy: Evidence for the central role of energy compromise in disease pathogenesis. Hum Mol Genet 2001; 10: 1215-1220 